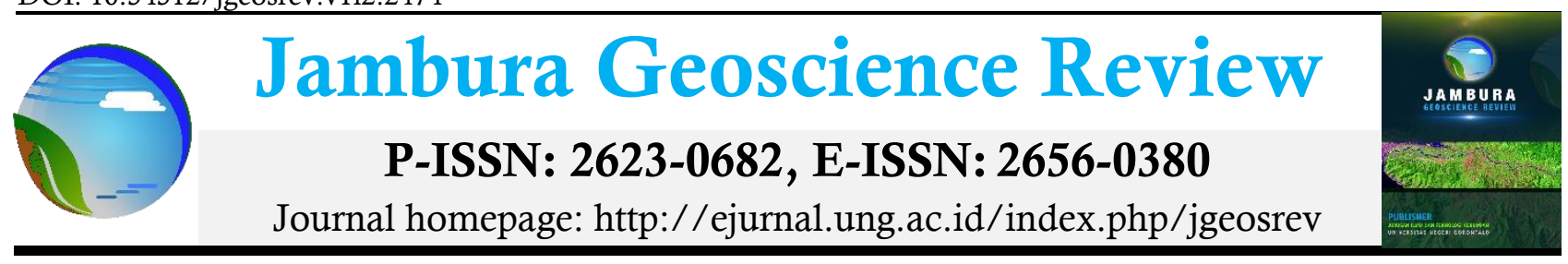

\title{
ANALISIS TINGKAT KERENTANAN LONGSOR DAERAH MUARA SUNGAI BONE KOTA GORONTALO
}

\author{
Muhammad Iqbal Asiki ${ }^{a}$, Sri Maryati ${ }^{a}$, Noviar Akase ${ }^{a}$ \\ ${ }^{a}$ Teknik Geologi, Universitas Negeri Gorontalo, Jl. Jendral Sudirman, No. 6, Kota Gorontalo, 96128, Indonesia
}

\section{INFO ARTIKEL}

\section{Status artikel:}

Diterima: 24 Juli 2019

Disetujui: 31 Juli 2019

Tersedia online: 31 Juli 2019

\section{Kata Kunci:}

Class of Landslide Susceptibility; GIS; Landslide

Penulis korespondensi:

Muhammad Iqbal Asiki

Program Studi Teknik Geologi, Jurusan

Ilmu dan Teknologi Kebumian,

Universitas Negeri Gorontalo

J1. Jenderal Sudirman No.6, Kota

Gorontalo. 96128, Indonesia

Email: iqbal.asiki96@gmail.com

\begin{abstract}
In Gorontalo City there have been 11 landslides in 2017 which are spread in 3 sub-districts namely Hulonthalangi, Kota Barat, and Dumbo Raya. While in 2018 there was a landslide in Tenda village which claimed two lives. The research site is located in coordinate $00^{\circ} 29^{\prime} 00^{\prime \prime}-00^{\circ} 31^{\prime} 51^{\prime \prime} \mathrm{N}$ and $123^{\circ} 3^{\prime} 00^{\prime \prime}$ $123^{\circ} 5^{\prime} 27^{\prime \prime}$ E with the wide of area 2,531 Ha consisting of 1,745 $\mathrm{Ha}$ of the mainland and $786 \mathrm{Ha}$ of the sea. The research area administratively is located in Dumbo Raya Sub-district, Gorontalo city, Gorontalo Province. The purpose of this study was to determine the level of landslide susceptibility in the study area and make zonation maps of landslide prone area. This research method applied in this study was integration of field survey and GIS analysis. The parameters which influence the landslide are lithology, precipitation, slope, lineament density, type of soil, and the land use. Based on the analysis of landslide susceptibility, the level of susceptibility in the research site consists of 3 classes; low, moderate, and high. The low class of landslide susceptibility has the area of $217.46 \mathrm{Ha}$, the moderate class of landslide susceptibility has the area of 338.93 Ha with the biggest spread is in Leato Selatan village; $102.68 \mathrm{Ha}$. The high class of landslide susceptibility has the area of $1,188.70 \mathrm{Ha}$ with the biggest spread in Leato Selatan Village; $288.66 \mathrm{Ha}$.
\end{abstract}

Copyright $\odot 2019$ JGeosREV-UNC This open access article is distributed under a Creative Commons Attribution (CC-BY) 4.0 International license

\section{Pendahuluan}

Tanah longsor adalah suatu bentuk pergerakan tanah yang pengangkutan atau pemindahan materialnya terjadi pada suatu saat dalam volume yang besar (Arifin et al., 2006). Tanah longsor adalah bencana geologi yang serius yang terjadi pada daerah dengan morfologi berlereng dan curah hujan yang tinggi dan dapat menimbulkan korban jiwa dan berdampak pada alam atau lingkungan (Ramani et al., 2011). Menurut data Badan Nasional Penanggulangan Bencana pada tahun 2017 ada 22 kejadian longsor yang terjadi di Sulawesi (BNPB, 2019). Selain itu, pada tahun 2018 jumlah kejadian meningkat menjadi 35 kejadian dalam setahun (BNPB, 2019). Sementara itu, Badan Penanggulangan Bencana Daerah (BPBD) Kota Gorontalo mengatakan terdapat tiga kecamatan yang rentan terhadap longsor di Kota Gorontalo yakni Hulonthalangi, Kota Barat, dan Dumbo Raya (Akuba, 2018). Pada tahun 2017 sudah terjadi 11 bencana tanah longsor yang melanda Kota Gorontalo dan tersebar di tiga kecamatan tersebut. Pada tahun 2018, tepatnya 31 Maret 2018 terjadi insiden longsor yang menelan dua korban jiwa di Kelurahan Tenda, Kecamatan Hulonthalangi (Akuba, 2018).

Tanah longsor merupakan bencana yang dapat diprediksi kedatangannya karena berhubungan dengan tingginya curah hujan suatu daerah. Selain itu, faktor lain seperti jenis batuan, struktur geologi, kemiringan lereng, dan penggunaan lahan juga merupakan indikator peran terhadap kejadian longsor (Dewi et al., 2017). Korban yang ditimbulkan akibat tanah longsor tidak sedikit jumlahnya baik korban jiwa maupun korban materi. Oleh karenanya, untuk mengantisipasi dan meminimalisir resiko yang ditimbulkan maka perlu dilakukan pemetaan daerah - daerah yang rentan terhadap longsor secara cepat dan efisien. Pemetaan daerah yang rentan terhadap longsor secara cepat dan efisien dapat 
dilakukan dengan memanfaatkan sistem informasi geografis (SIG). Proses input, kalkulasi, dan output data dapat dibaca dan diproses dengan mudah dan cepat (Pradhan \& Ahmed, 2010). Pemetaan daerah yang rentan terhadap longsor telah dilakukan oleh peneliti sebelumnya antara lain Daneshvar \& Ali (2011) yang meneliti tentang zonasi bahaya tanah longsor dengan analisis sistem informasi geografis di Daerah Aliran Sungai (DAS) Golmakan di bagian timur laut Iran; Dewi et al., (2017) yang meneliti tentang zonasi rawan bencana tanah longsor dengan analisis geography information system (GIS) di Kecamatan Bagelen; dan Yunianto (2011) yang meneliti tentang analisis kerawanan tanah longsor dengan aplikasi sistem informasi geografis dan penginderaan jauh di Kabupaten Bogor.

Penelitian ini menggunakan 6 parameter penyebab longsor yaitu litologi, kemiringan lereng, curah hujan, densitas kelurusan, jenis tanah, dan penggunaan lahan. Tujuan dari penelitian ini adalah untuk mengetahui litologi penyusun daerah penelitian, menentukan tingkat kerentanan longsor daerah penelitian dan membuat peta zonasi tingkat kerentanan longsor daerah penelitian.

\section{Metodologi}

\subsection{Lokasi Penelitan}

Secara administratif daerah penelitian berada di daerah muara Sungai Bone, Kota Gorontalo, Provinsi Gorontalo (Gambar 1). Daerah penelitian berada pada koordinat $00^{\circ} 29^{\prime} 00^{\prime \prime}-00^{\circ} 31^{\prime} 5^{\prime \prime}$ LU dan $123^{\circ} 3^{\prime} 00^{\prime \prime}-123^{\circ} 5^{\prime} 27^{\prime \prime}$ BT dengan luas wilayah 2.531 Ha yang terdiri dari 1.745 Ha daratan dan 786 Ha perairan.

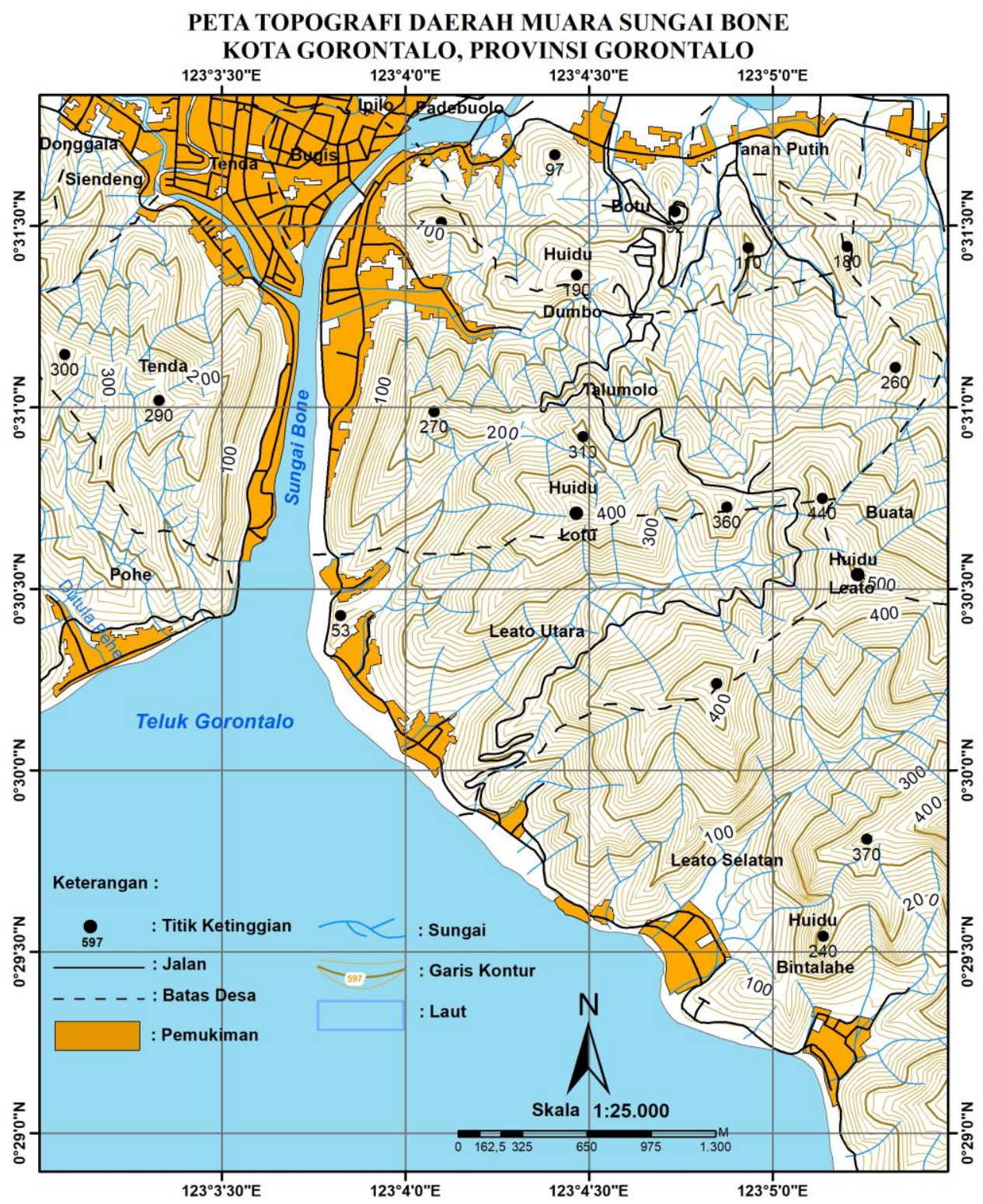

Gambar 1. Peta administrasi lokasi penelitian 


\section{PETA GEOLOGI DAERAH MUARA SUNGAI BONE KOTA GORONTALO, PROVINSI GORONTALO}

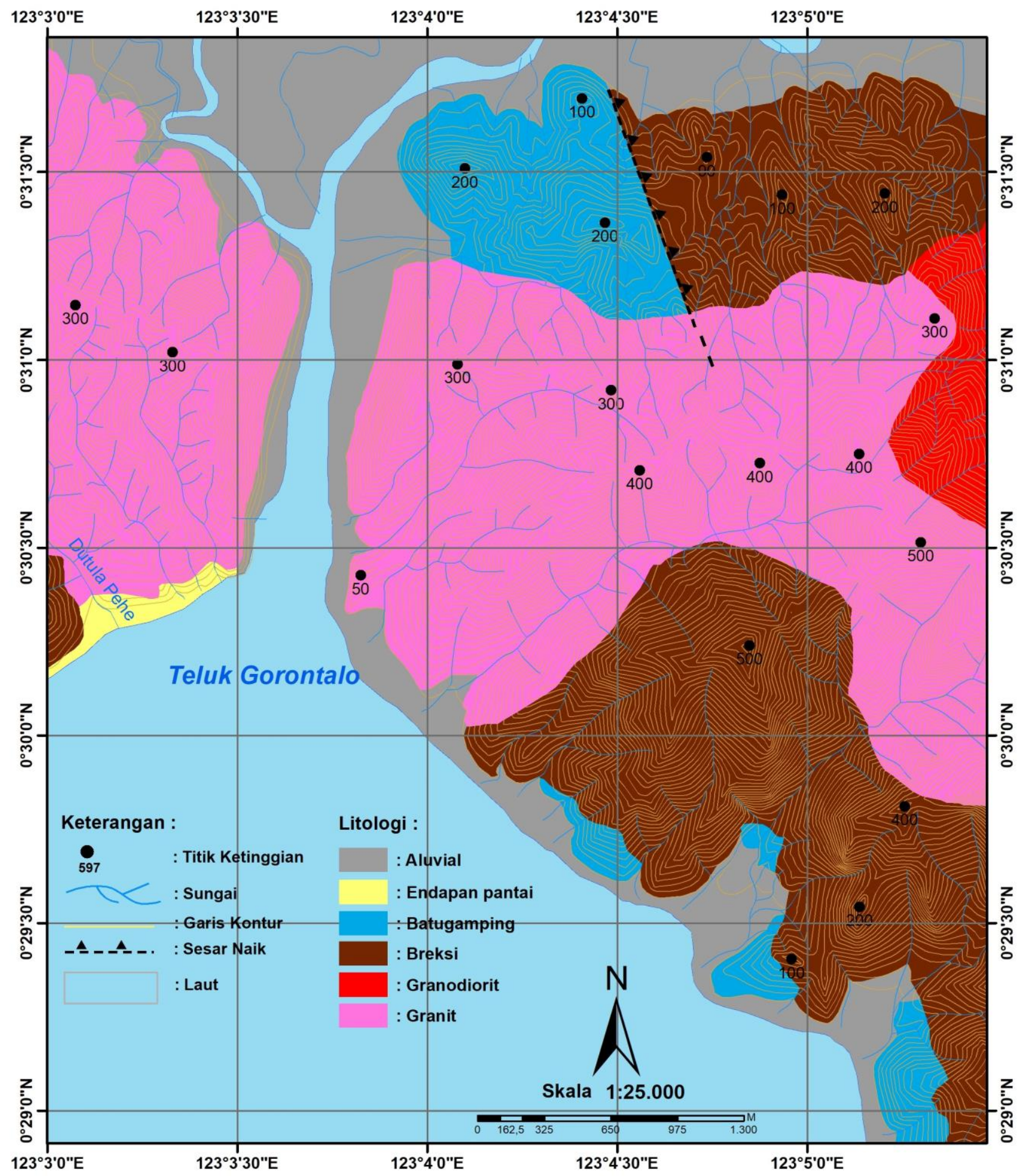

Gambar 2. Peta geologi daerah penelitian

\subsection{Metode Penelitian}

Metode penelitian yang digunakan dalam penelitian ini adalah survei lapangan dan analisis Sistem Informasi Geografis (SIG). Survei lapangan yang dilakukan adalah berupa pengumpulan data-data lapangan seperti data geologi berupa litologi penyusun daerah penelitian serta validasi data lapangan setelah didapatkan tingkat kerentanan longsor daerah penelitian. Analisis Sistem Informasi Geografis (SIG) dilakukan dengan metode Multi Criteria Evaluation (MCE) yaitu skoring dan pembobotan faktorfaktor yang berpengaruh terhadap terjadinya tanah longsor yaitu litologi, densitas kelurusan, 
Tabel 1. Kelas kerentanan longsor

\begin{tabular}{ll}
\hline Kelas kerentanan & Skor \\
\hline Rendah & Nilai minimum - (interval kelas + nilai minimum) \\
Sedang & $>$ skor kerawanan rendah $-($ skor kerawanan rendah + interval kelas $)$ \\
Tinggi & $>$ skor kerawanan sedang - nilai maksimum
\end{tabular}

kemiringan lereng, jenis tanah, curah hujan, dan penggunaan lahan. Selanjutnya, parameter parameter tersebut di-overlay untuk kemudian dilakukan perhitungan untuk mendapatkan tingkat kerentanan longsor. Hasil yang diperoleh berupa peta zonasi tingkat kerentanan longsor daerah penelitian. Analisis tingkat kerentanan longsor dilakukan dengan menggunakan model pendugaan tanah longsor oleh Balai Besar Sumberdaya Lahan Pertanian (BBSDLP, 2009 dalam Dewi et al., 2017).

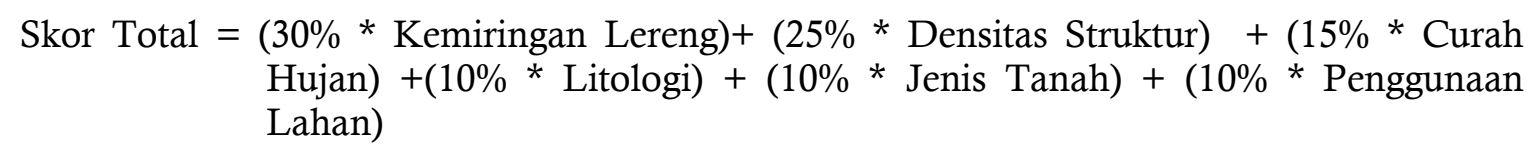

selanjutnya, dilakukan perhitungan untuk mendapatkan interval kelas untuk dimasukkan dalam tabel kelas kerentanan longsor dengan menggunakan persamaan 2.

$\mathrm{I}=\frac{\boldsymbol{R}}{\boldsymbol{K}}$

dimana : I adalah interval kelas; $\mathrm{R}$ adalah range (data terbesar - data terkecil) dari skor total; dan $\mathrm{K}$ adalah banyak kelas yang akan dibuat.

selanjutnya dibuat klasifikasi kelas kerentanan longsor dengan interval kelas yang diperoleh dari persamaan 2 sehingga klasifikasi kelas kerentanan longsor menjadi seperti dalam Tabel 1.

\section{Hasil dan Pembahasan}

\subsection{Parameter Kerentanan Longsor \\ 3.1.1. Litologi}

Berdasarkan peta geologi lembar Leato dan sekitarnya dan peta geologi lembar Bongo dan sekitarnya daerah penelitian disusun oleh 6 satuan batuan yaitu satuan granit, satuan granodiorit, satuan breksi vulkanik, satuan batugamping terumbu, satuan endapan pantai, dan satuan aluvial (Tabel 2). Masing - masing jenis batuan diberi skor sesuai dengan tingkat kepekaannya terhadap longsor. Semakin tinggi skor yang diberikan maka semakin tinggi pengaruhnya terhadap terjadinya longsor. Gambaran sebaran jenis batuan pada daerah penelitian dapat dilihat dalam Gambar 2.

\subsubsection{Curah Hujan}

Data curah hujan yang digunakan dalam penelitian diambil dari empat pos pengamatan curah hujan di sekitar Kota Gorontalo yaitu pos Dumbo Raya, BPTPH Kota Utara, BP3K Botupingge, dan pos Telaga. Data curah hujan tersebut menunjukkan bahwa, curah hujan Kota Gorontalo berkisar antara $<1.150 \mathrm{~mm} /$ tahun sampai $1.590 \mathrm{~mm} /$ tahun (Tabel 3). Semakin tinggi curah hujan maka pengaruhnya terhadap kejadian longsor juga semakin tinggi. Gambaran spasial tingkat curah hujan Kota Gorontalo dan sekitarnya dapat dilihat dalam Gambar 3.

Tabel 2. Jenis litologi (Dewi et al., 2017)

\begin{tabular}{llll}
\hline No & Litologi & Luas $(\mathrm{Ha})$ & Skor \\
\hline 1 & Aluvial dan endapan pantai & 256,12 & 1 \\
2 & Granit dan granodiorit & 968,11 & 3 \\
3 & Batugamping & 131,1 & 3 \\
4 & Breksi vulkanik & 381,76 & 5 \\
\hline
\end{tabular}

Tabel 3. Curah Hujan (modifikasi dari Sulistiarto, 2008)

\begin{tabular}{llll}
\hline No & Curah hujan & Tahun & Skor \\
\hline 1 & $1000-1150$ & 2018 & 1 \\
2 & $1150-1250$ & 2018 & 2 \\
3 & $1250-1350$ & 2018 & 3 \\
4 & $1350-1450$ & 2018 & 4 \\
5 & $1450-1590$ & 2018 & 5 \\
\hline
\end{tabular}




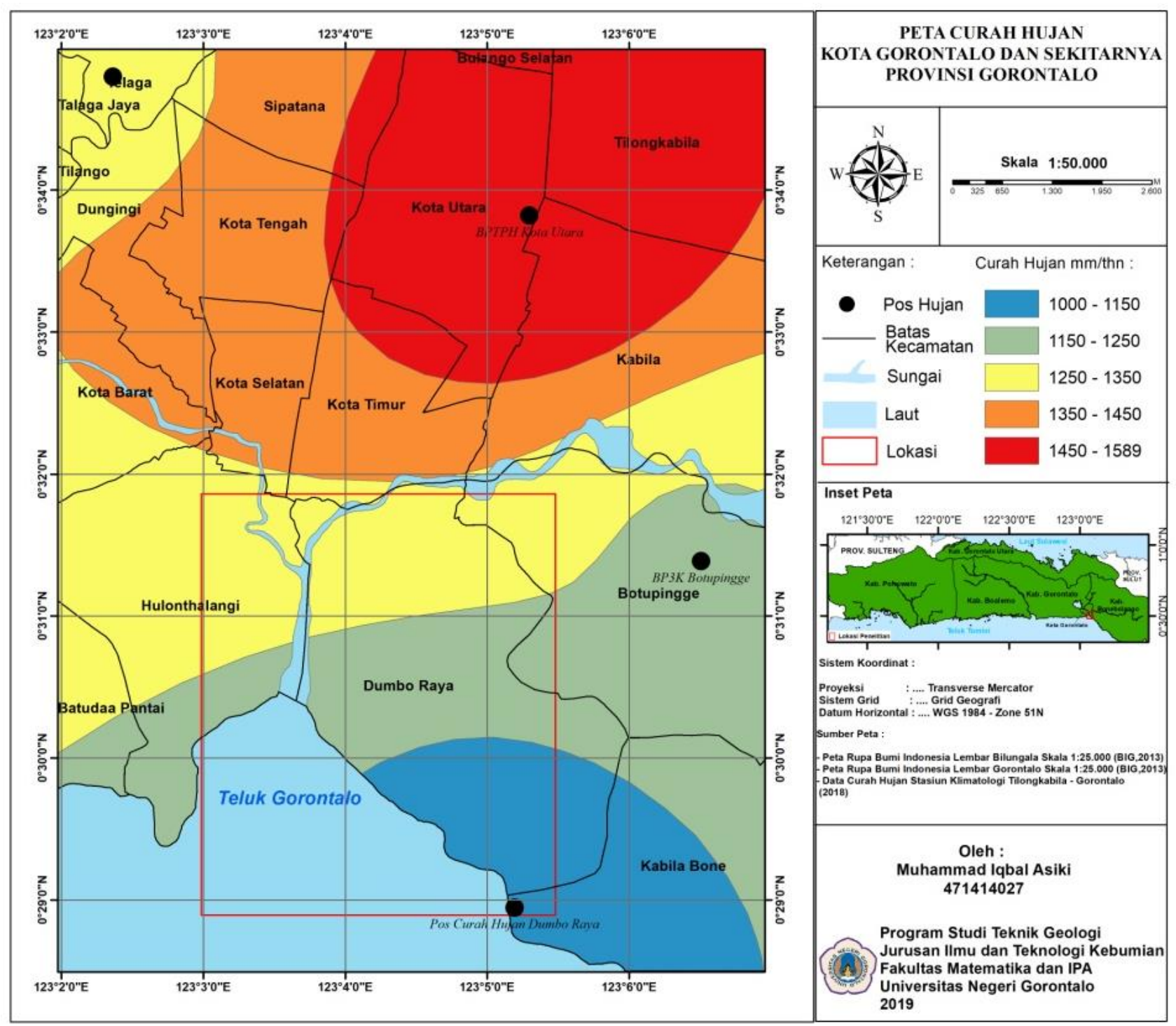

Gambar 3.Peta curah hujan daerah penelitian

Curah hujan merupakan salah satu faktor pemicu terjadinya tanah longsor. Kekuatan depresi hujan terhadap tanah, jumlah dan kecepatan aliran permukaan serta kerusakan longsor ditentukan oleh besarnya intensitas dan distribusi curah hujan (Barus, 1999).

\subsubsection{Kemiringan Lereng}

Kemiringan lereng merupakan faktor yang paling mempengaruhi terjadinya longsor. Daerah muara Sungai Bone dan sekitarnya merupakan daerah yang memiliki kemiringan lereng yang bervariasi (Tabel 4). Kemiringan lereng $<7 \%$ dengan luas $149,35 \mathrm{Ha}$ digunakan sebagai kawasan permukiman. Akan tetapi kawasan ini dikelilingi oleh perbukitan dengan kemiringan lereng $>30-70 \%$ dengan luas total 1.197,93 Ha yang merupakan kemiringan lereng yang mendominasi daerah muara Sungai Bone dan sekitarnya. Menurut Wang et al., (2015) tanah longsor merupakan gerakan massa yang terjadi di lereng curam di bawah pengaruh gravitasi. Semakin tinggi tingkat kemiringan lereng suatu daerah maka akan semakin tinggi pula potensi longsor pada daerah tersebut. Gambaran spasial tingkat kemiringan lereng daerah muara sungai Bone dan sekitarnya dapat dilihat pada Gambar 4.

Tabel 4. Kemiringan lereng (Yunianto, 2011)

\begin{tabular}{llll}
\hline No & Kemiringan lereng $(\%)$ & Luas $(\mathrm{Ha})$ & Skor \\
\hline 1 & $<7$ & 149,35 & 1 \\
2 & $>7-15$ & 103,60 & 2 \\
3 & $>15-30$ & 247,59 & 3 \\
4 & $>30-70$ & $1.197,93$ & 4 \\
5 & $>70$ & 46,83 & 5 \\
\hline
\end{tabular}




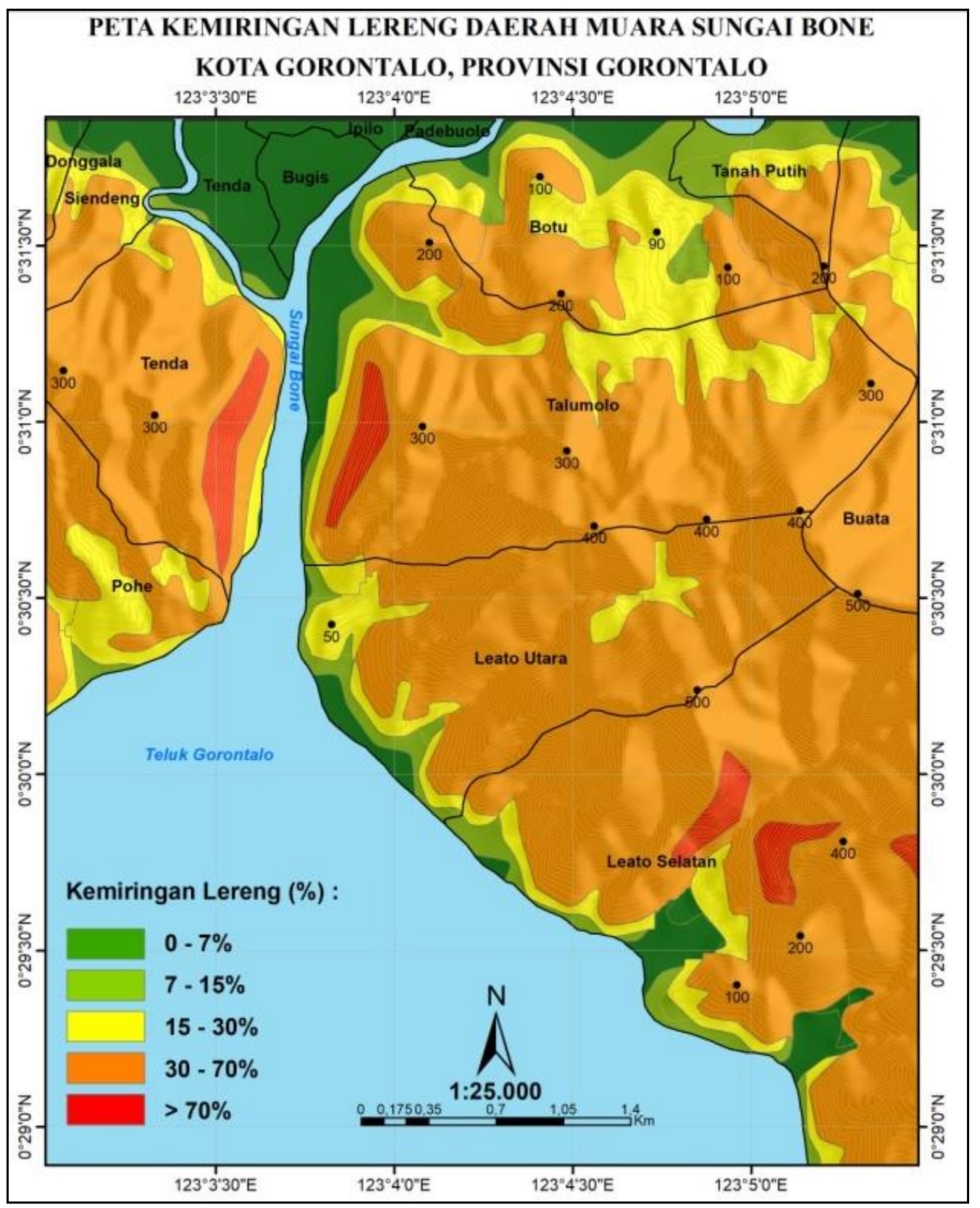

Gambar 4. Peta kelerengan daerah penelitian

\subsubsection{Jenis Tanah}

Berdasarkan data Balai Besar Sumber Daya Lahan Pertanian tahun 2011 jenis tanah pada daerah penelitian terdiri dari mediteran merah kuning, brown forest soil, dan aluvial (Tabel 5). Berdasarkan klasifikasi Dudal \& Suparaptoharjo (1957) deskripsi jenis tanah pada daerah penelitian dapat diuraikan sebagai berikut.

\section{a. Tanah Aluvial}

Tanah aluvial adalah tanah yang berasal dari endapan aluvial maupun koluvial muda. Perkembangan profil tanah lemah sampai tidak ada. Sifat tanah tergantung dari bahan induk yang diendapkannya serta penyebarannya tidak dipengaruhi oleh ketinggian maupun iklim. Tanah ini mempunyai tingkat kepekaan rendah terhadap longsor. Jenis tanah ini terdapat pada bagian utara dari daerah penelitian (Gambar 5).

Tabel 5. Data Jenis Tanah (Sobirin, 2013 dalam Sugianti et al, 2014)

\begin{tabular}{ll}
\hline Jenis Tanah & Skor \\
\hline Aluvial & 1 \\
Brown Forest Soil, Mediteran & 3 \\
\hline
\end{tabular}




\section{b. Brown Forest Soil}

Merupakan bagian dari kelompok tanah Calcisol yang kaya akan kalsium. Tanah jenis ini mempunyai tingkat kepekaan sedang terhadap longsor.

\section{c. Tanah Mediteran Merah Kuning}

Tanah mediteran merah kuning adalah tanah yang berkembang dari bahan induk batu kapur dengan kadar bahan bahan organik yang rendah, kejenuhan bersifat basa hingga tinggi, tekstur berat dengan struktur tanah gumpal, reaksi tanah dari agak masam sampai sedikit alkalis ( $\mathrm{pH} 6,0-7,5)$. Tanah ini terdapat pada daerah mulai dari muka laut sampai $400 \mathrm{~m}$ pada iklim tropis basah dengan bulan kering nyata dan curah hujan tahunan antara $800-2500 \mathrm{~mm}$. Tanah ini mempunyai tingkat kepekaan sedang terhadap longsor. Jenis tanah ini mendominasi daerah penelitian, tersebar mulai dari bagian utara sampai ke bagian selatan dari daerah penelitian (Gambar 5).

\subsubsection{Penggunaan Lahan}

Penggunaan lahan merupakan salah satu faktor penyebab terjadinya tanah longsor. Penggunaan lahan pada daerah penelitian terdiri dari hutan, semak belukar, permukiman, perkebunan dan ladang, dan lahan kosong (Tabel 6). Penggunaan lahan berpengaruh terhadap kestabilan lahan, kontrol terhadap kejenuhan air, serta kekuatan ikatan partikel tanah (Yunianto, 2011). Lahan yang ditutupi oleh hutan atau perkebunan akan lebih bisa menjaga kestabilan lahan karena sistem perakaran yang dalam sehingga akan menjaga kekompakkan antar partikel tanah dan antara partikel tanah dengan batuan dasar. Sementara itu, tegalan, sawah, dan semak belukar memiliki sistem perakaran yang dangkal dan bersifat tergenang sehingga tidak mampu menjaga stabilitas lahan dan kekompakan

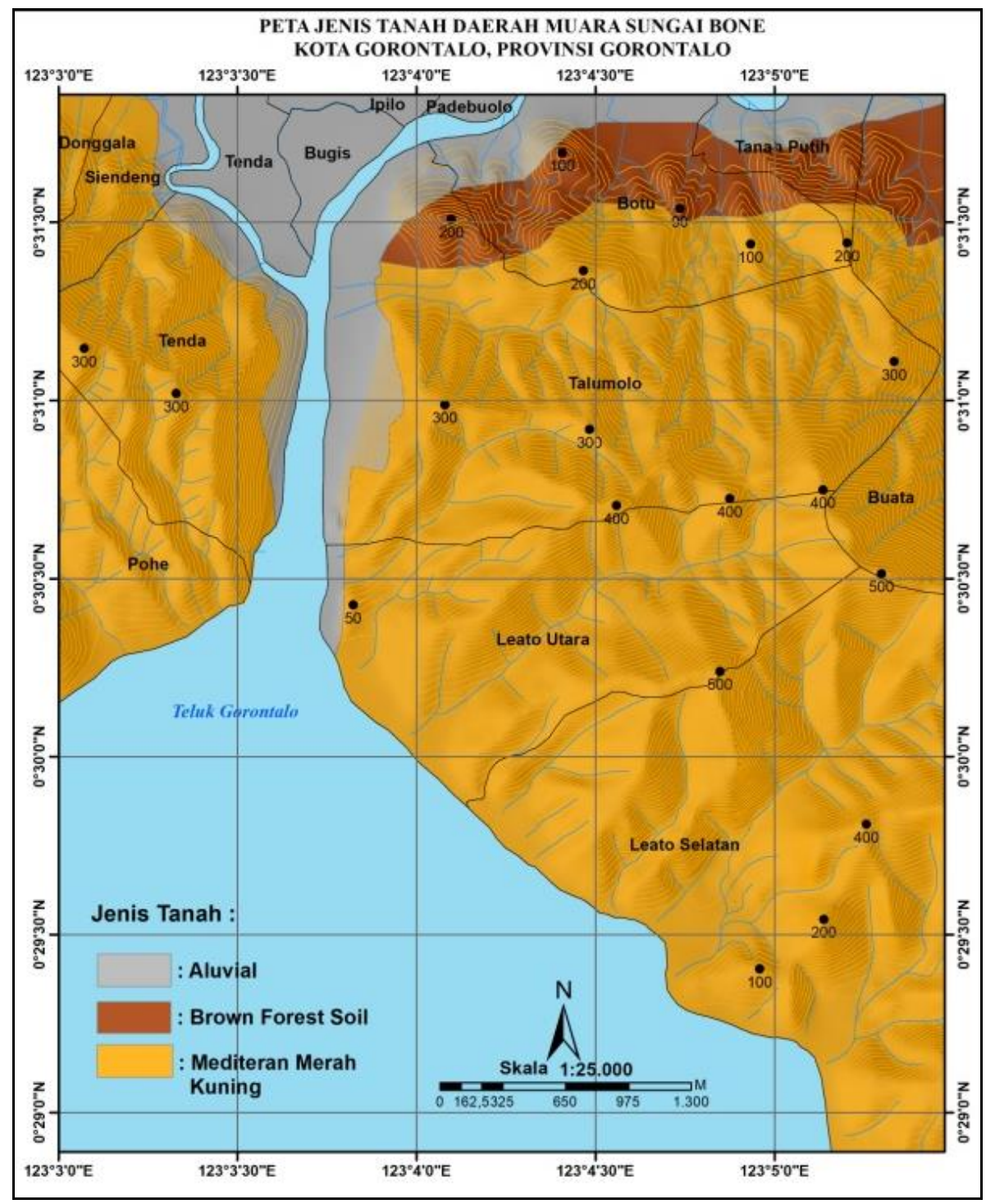

Gambar 5. Peta jenis tanah daerah penelitian 
Tabel 6. Penggunaan lahan (Yunianto, 2011)

\begin{tabular}{llll}
\hline No & Penggunaan lahan & Luas $(\mathrm{Ha})$ & Skor \\
\hline 1 & Hutan & 1.372 .16 & 1 \\
2 & Semak Belukar & 26,77 & 2 \\
3 & Permukiman & 280,74 & 3 \\
4 & Perkebunan dan Ladang & 44,26 & 4 \\
5 & Lahan Kosong & 21,06 & 5
\end{tabular}

partikel tanah (Rahmat, 2010). Wahyunto et al., (2007) mengatakan penggunaan lahan seperti persawahan, maupun tegalan dan semak belukar, terutama pada daerah-daerah berlereng terjal umumnya sering terjadi tanah longsor. Distribusi spasial penggunaan lahan pada daerah penelitian dapat dilihat dalam Gambar 6.

\subsubsection{Densitas Kelurusan}

Kelurusan adalah suatu aliran yang lurus dan lembah, permukaan yang lurus, perubahan tonal tanah, kelurusan daerah vegetasi, perubahan dari perbedaan tipe vegetasi serta ketinggiannya, atau perbedaan topografi yang mencolok. Semua fenomena ini mungkin hasil dari fenomena struktur yang terjadi seperti sesar (patahan), kekar, lipatan, dan rekahan (Hung et al., 2005). Dalam analisis densitas kelurusan, kelurusan yang teridentifikasi merupakan pola kelurusan sungai ataupun gawir yang dihasilkan oleh aktivitas sesar (Chemong \& Piyaphong, 2013).

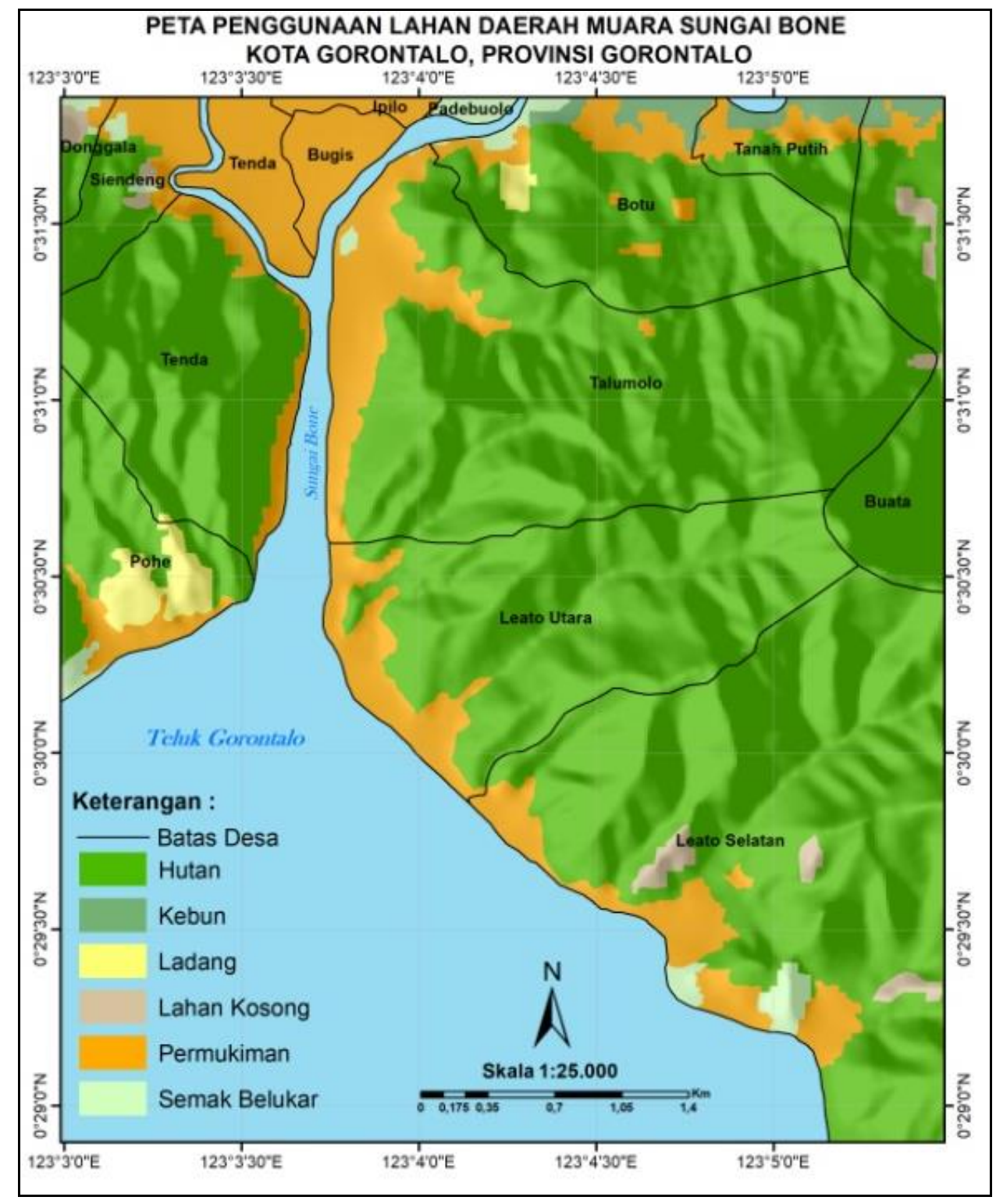

Gambar 6. Peta penggunaan lahan daerah penelitian 


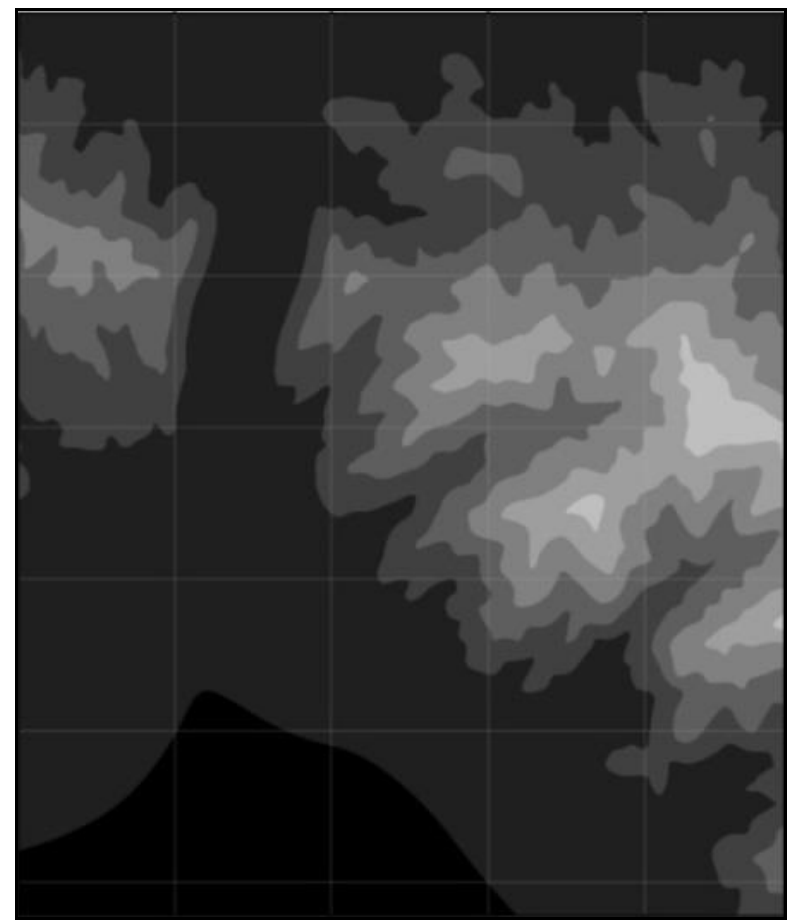

Gambar 7. Citra DEM daerah penelitian
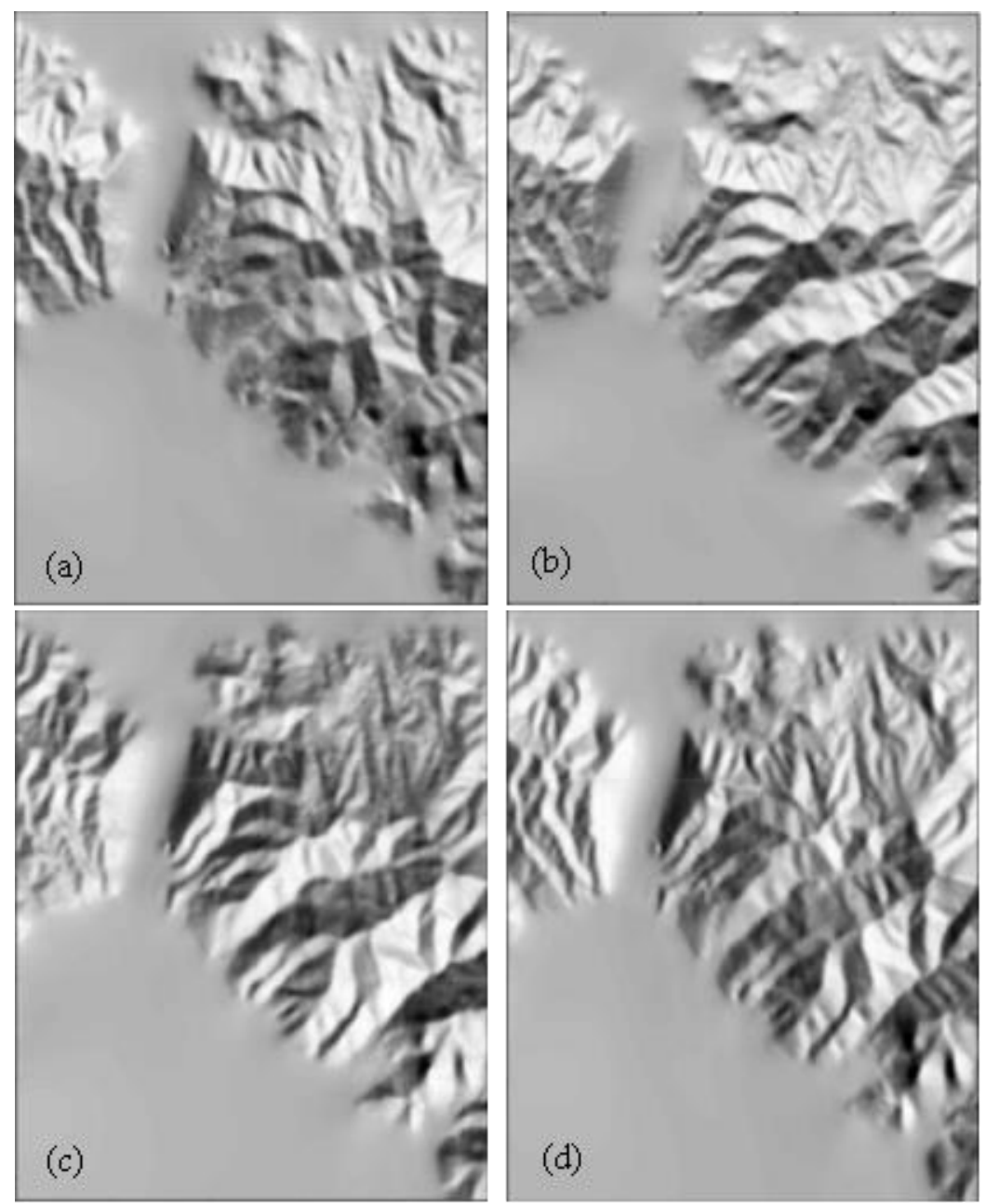

Gambar 8. Citra hillshade dengan sudut penyinaran (a) $0^{\circ}$, (b) $45^{\circ}$, (c) $90^{\circ}$, dan (d) $135^{\circ}$

Pola kelurusan merupakan indikasi adanya struktur geologi. Struktur geologi merupakan salah satu faktor yang memengaruhi terjadinya longsor. Struktur geologi yang terjadi pada batuan dapat memengaruhi kestabilan lereng karena dapat mengurangi daya ikat batuan sehingga resistensi batuan 

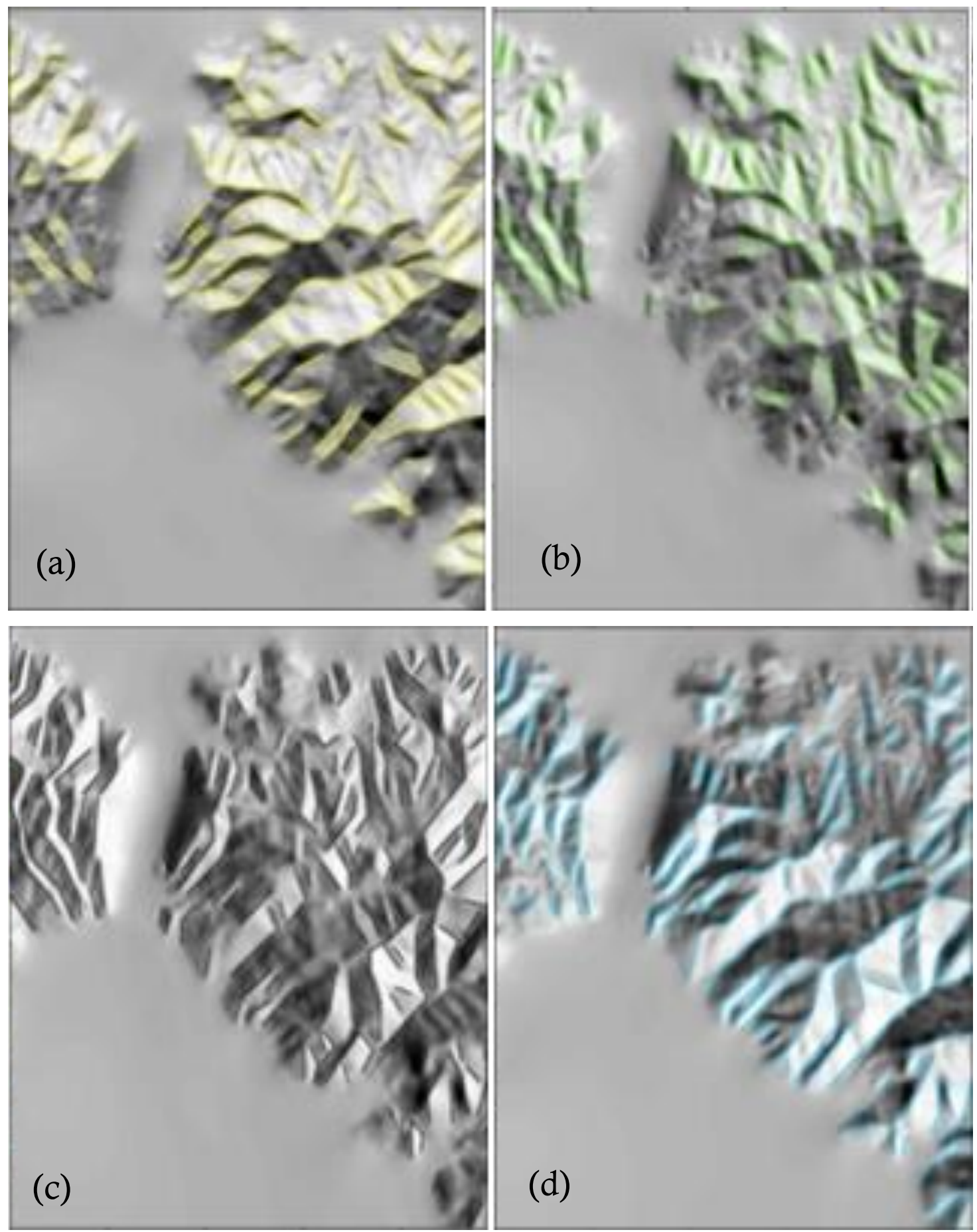

Gambar 9. Hasil ekstraksi kelurusan (a) $0^{\circ}$, (b) $45^{\circ}$, (c) $90^{\circ}$, dan (d) $135^{\circ}$

berkurang. Akibatnya, potensi untuk terjadi longsor juga lebih tinggi. Densitas kelurusan dianalisis menggunakan analisis spasial. Data berupa peta kontur daerah penelitian diubah menjadi data DEM (Digital Elevation Mode) lalu kemudian dibuat menjadi citra hillshade dengan sudut penyinaran $0^{0}, 45^{\circ}$, $90^{\circ}$, dan $135^{\circ}$ menggunakan software ArcGIS 10.3 (Gambar 7 dan 8).

Setelah itu diolah menggunakan software PCI Geomatica 2015 untuk mendapatkan pola kelurusan secara otomatis dari masing-masing citra hillshade (Gambar 9). Kelurusan otomatis dibuat dengan memanfaatkan algorithma Line yang ada pada software PCI Geomatica. Hasil dari ekstraksi kelurusan kemudian digabung menjadi satu (Gambar 10). Setelah itu dibuat grid berukuran $1 \mathrm{x} 1 \mathrm{~km}^{2}$ dan dipotongkan dengan kelurusan yang telah digabung sebelumnya. Selanjutnya dihitung jumlah panjang dari kelurusan yang berada di dalam grid untuk mendapatkan nilai densitas dari kelurusan tersebut (Tabel 7). 


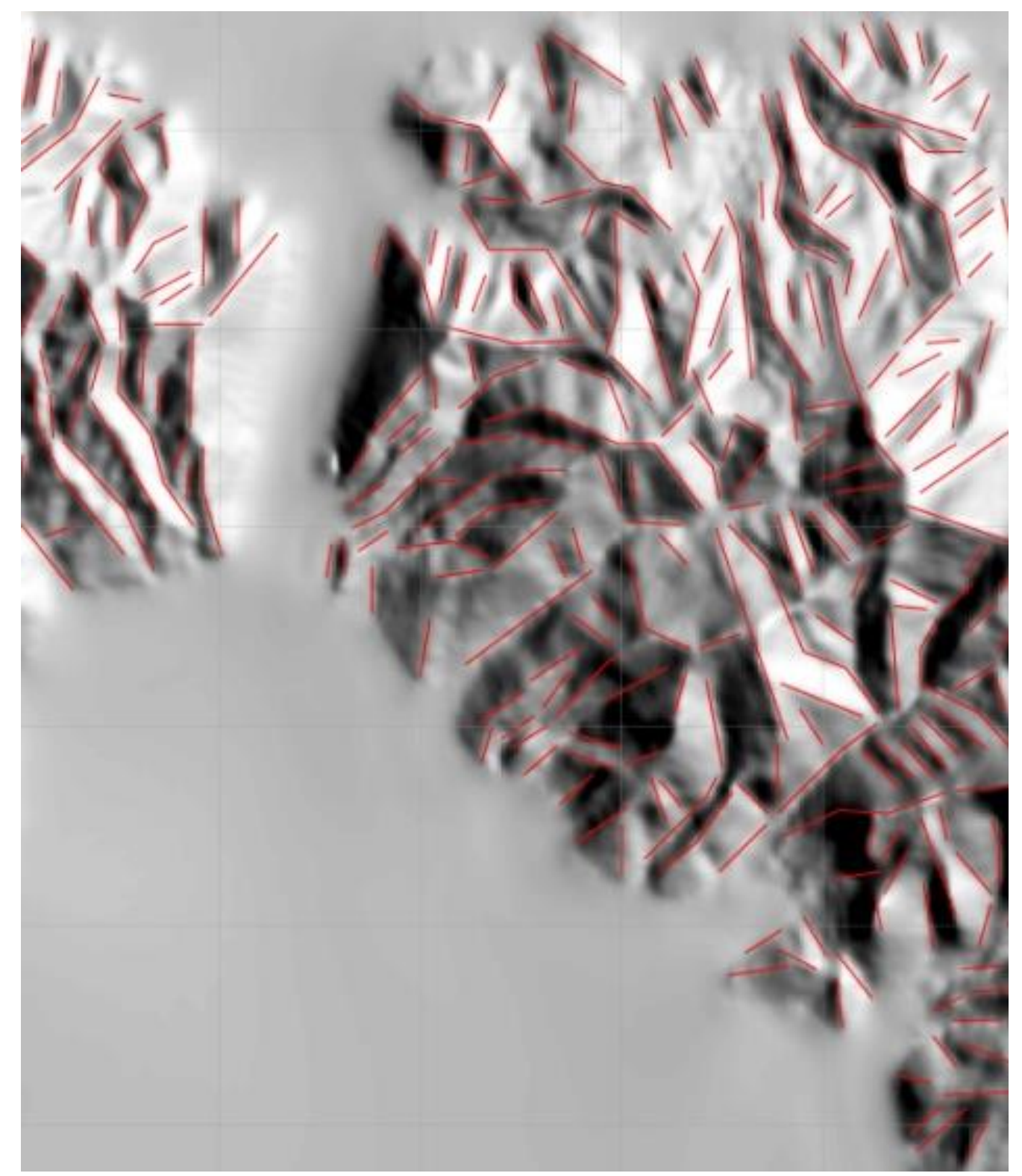

Gambar 10. Gabungan dari keempat hasil ekstraksi

Tabel 7. Data Densitas Kelurusan (Adama et al, 2017)

\begin{tabular}{llll}
\hline No & Densitas Kelurusan & Nilai Densitas $\mathrm{km} / \mathrm{km}^{2}$ & Skor \\
\hline 1 & Rendah & $<3,36$ & 1 \\
2 & Sedang & $>3,36-6,66$ & 3 \\
3 & Tinggi & $>6,66$ & 5 \\
\hline
\end{tabular}

Hasil analisis kelurusan daerah penelitian menunjukkan bahwa semakin ke arah utara tingkat densitas kelurusan semakin rendah. Sedangkan pada bagian timur dan barat daerah penelitian tingkat densitas kelurusan antara sedang sampai tinggi (Gambar 11).

\subsubsection{Analisis tingkat kerentanan longsor}

Model pendugaan tingkat kerentanan tanah longsor dilakukan dengan menggunakan model pendugaan yang digunakan dalam penelitian yang dilakukan oleh Dewi et al., (2017) yang bersumber dari Balai Besar Sumberdaya Lahan Pertanian (BBSDLP). Berdasarkan model pendugaan tersebut parameter yang digunakan adalah litologi, kemiringan lereng, curah hujan, densitas kelurusan (lineament density), penggunaan lahan, dan jenis tanah. Seluruh parameter tersebut kemudian diklasifikasikan berdasarkan skor dan diberi bobot sesuai kontribusinya masing-masing terhadap terjadinya longsor. Setelah itu, seluruh parameter tersebut kemudian di-overlay untuk menghasilkan peta zonasi tingkat kerentanan longsor. Klasifikasi kelas kerentanan longsor disajikan dalam Tabel 8. 


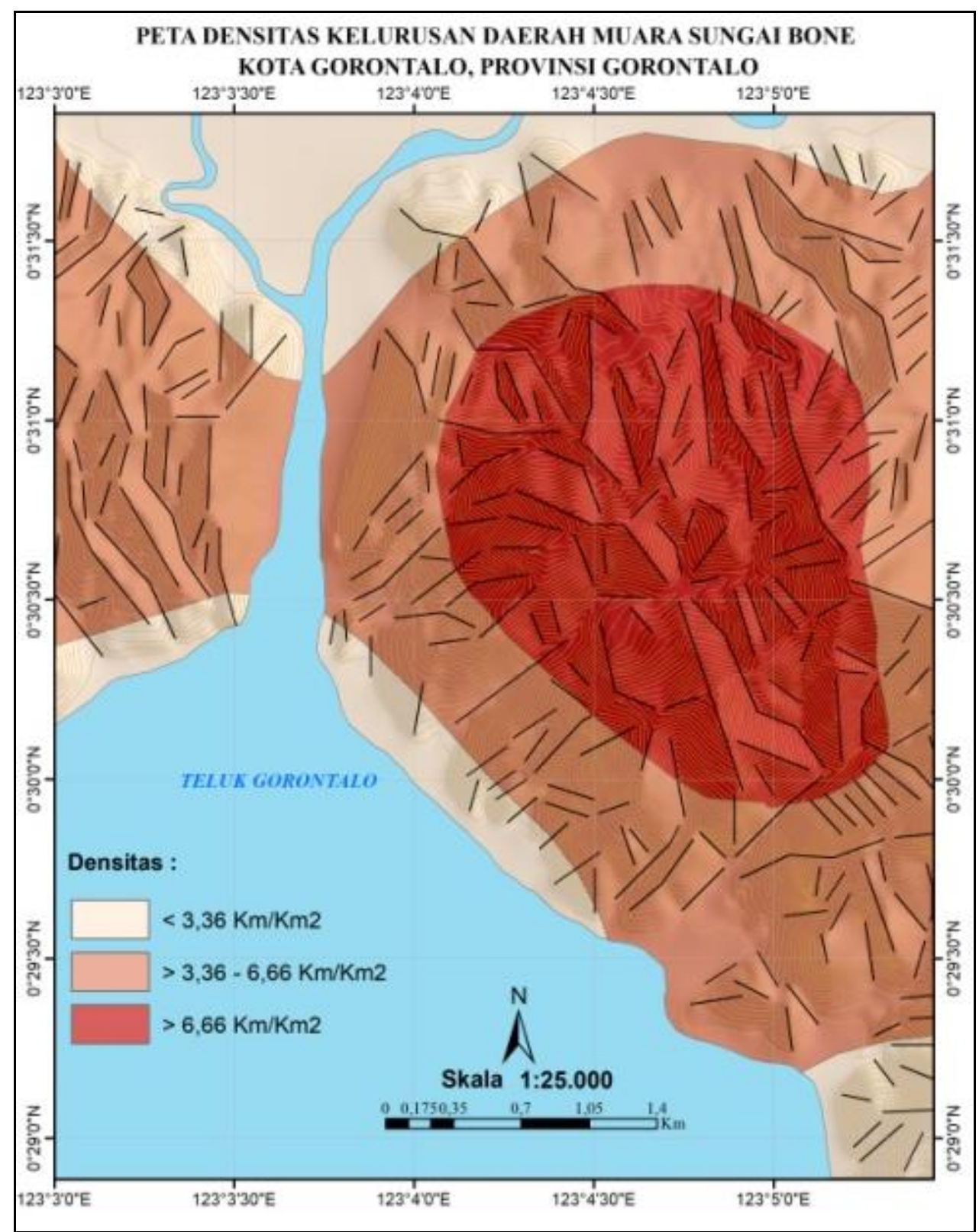

Gambar 11. Gabungan dari keempat hasil ekstraksi

Tabel 8. Klasifikasi Kelas Kerentanan Longsor

\begin{tabular}{lll}
\hline No & Kelas Kerentanan & Interval Kelas \\
\hline 1 & Rendah & $1,02-2,06$ \\
2 & Sedang & $>2,06-2,92$ \\
3 & Tinggi & $>2,92-3,8$ \\
\hline
\end{tabular}

Berdasarkan hasil analisis dan perhitungan, daerah muara Sungai Bone dan sekitarnya memiliki tiga kelas kerentanan longsor yaitu kelas kerentanan longsor rendah, kelas kerentanan longsor sedang, dan kelas kerentanan longsor tinggi. Pada daerah penelitian terdapat 23 titik longsor yang merupakan hasil validasi lapangan. Uraian dari ketiga kelas kerentanan longsor tersebut adalah sebagai berikut:

\section{a. Kelas kerentanan longsor rendah}

Kelas kerentanan longsor rendah merupakan wilayah yang memiliki tingkat kerentanan rendah untuk terjadinya tanah longsor atau bisa dikatakan bahwa wilayah ini tidak rentan terhadap terjadinya tanah longsor. Areal seluas 217,46 $\mathrm{Ha}$ atau 12,16\% dari daerah penelitian merupakan wilayah dengan kelas kerentanan longsor rendah. Penyebarannya sebagian besar berada di sebelah utara dari daerah penelitian yang meliputi 13 kelurahan. Penyebaran terluas berada di Kelurahan Leato Selatan dengan luas 38,59 Ha. Pada kelas ini tidak terdapat titik longsor. 


\section{PETA TINGKAT KERENTANAN LONGSOR DAERAII MUARA SUNGAI BONE} KOTA GORONTALO, PROVINSI GORONTALO

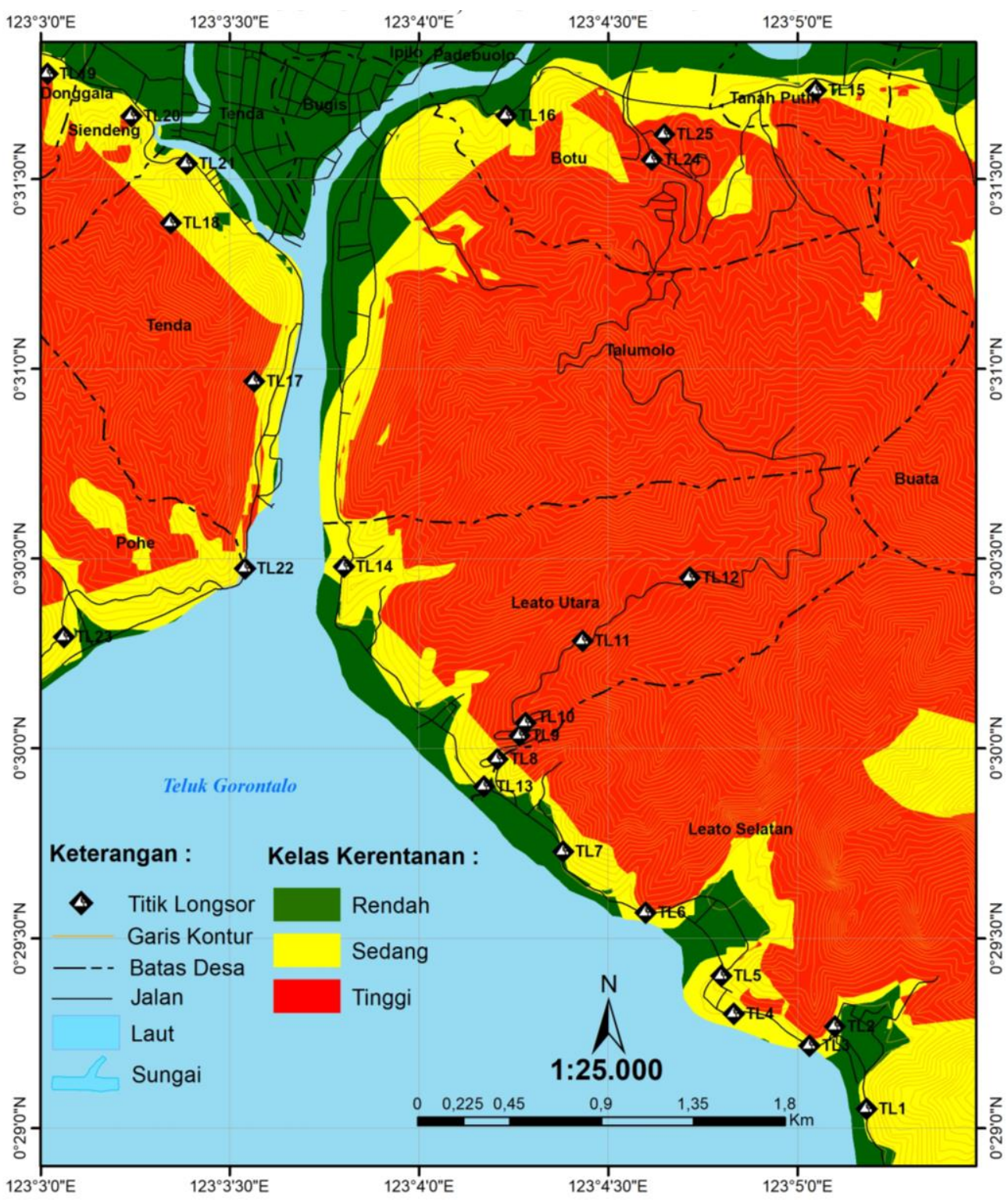

Gambar 12. Peta tingkat kerentanan longsor daerah muara Sungai Bone

\section{b. Kelas kerentanan longsor sedang}

Kelas kerentanan longsor sedang adalah daerah dengan tingkat kerentanan longsor sedang atau bisa dikatakan daerah ini rentan terhadap terjadinya tanah longsor. Tanah longsor besar maupun kecil dapat terjadi pada daerah ini terlebih lagi pada tebing pemotongan jalan, gawir, dan pada lereng yang mengalami gangguan. Areal dengan luas total 338,93 $\mathrm{Ha}$ atau 18,95\% dari daerah penelitian merupakan wilayah dengan kelas kerentanan longsor sedang yang tersebar di 10 kelurahan. Sebagian besar berada di sepanjang jalan utama di bagian timur dan barat dari Sungai Bone. Penyebaran terluasnya berada di Kelurahan Leato Selatan dengan luas sebesar 102, $68 \mathrm{Ha}$. Pada kelas ini terdapat 15 titik longsor yang tersebar di sepanjang jalan utama dari daerah penelitian.

\section{c. Kelas kerentanan longsor tinggi}

Kelas kerentanan longsor tinggi merupakan daerah yang memiliki tingkat kerentanan longsor tinggi atau daerah yang sangat rentan terhadap kejadian longsor. Daerah dengan tingkat kerentanan longsor tinggi akan sering mengalami tanah longsor baik tanah longsor besar maupun kecil. Longsoran lama masih ada dan aktif kembali akibat curah hujan tinggi dan dalam waktu yang lama serta erosi yang kuat. Lereng cenderung tidak stabil dan mempunyai kemiringan lereng yang curam ( kemiringan $30-70 \%$ ) sampai sangat curam ( $>70 \%$ ). Areal seluas $1.188,70 \mathrm{Ha}$ atau $66,48 \%$ dari luas daerah penelitian merupakan daerah dengan kelas kerentanan longsor tinggi. Kelas ini merupakan kelas yang 
paling mendominasi daerah penelitian. Tersebar di 10 kelurahan dengan penyebaran terluas berada di Kelurahan Leato Selatan yakni sebesar 288,66 Ha. Daerah dengan kelas kerentanan longsor tinggi harus diwaspadai karena sewaktu-waktu dapat terjadi tanah longsor, terlebih lagi saat memasuki musim penghujan. Distribusi kawasan yang rentan terhadap longsor pada daerah muara Sungai Bone dan sekitarnya dapat dilihat dalam Gambar 12. Pada kelas ini terdapat 8 titik longsor dan 2 diantaranya terdapat di Kelurahan Tenda yang menyebabkan korban jiwa sebanyak 2 orang dan 1 rumah rusak.

\section{Kesimpulan}

Analisis longsor menghasilkan tiga kelas kerentanan longsor yakni kelas kerentanan longsor rendah, kelas kerentanan longsor sedang, dan kelas kerentanan longsor tinggi. Kelas kerentanan longsor rendah mempunyai luas total sebesar 217,46 Ha yang tersebar di 13 kelurahan yang ada pada daerah penelitian. Sebagian besar berada di sepanjang jalan utama di bagian timur dan barat dari Sungai Bone. Penyebaran terluas berada di Kelurahan Leato Selatan dengan luas 38,59 Ha. Kelas kerentanan longsor sedang mempunyai luas total 338,93 Ha yang tersebar di 10 kelurahan yang ada pada daerah penelitian. Sebagian besar berada di sepanjang jalan utama di bagian timur dan barat dari Sungai Bone. Penyebaran terluasnya berada di Kelurahan Leato Selatan dengan luas sebesar 102, 68 Ha. Kelas kerentanan longsor tinggi mempunyai luas total sebesar 1.188,70 Ha dan merupakan kelas yang mendominasi daerah penelitian. Tersebar di 10 kelurahan dengan penyebaran terluas berada di Kelurahan Leato Selatan yakni sebesar 288,66 Ha. Rata - rata kelas kerawanan longsor tinggi terjadi pada kemiringan lereng tinggi yakni $30-70 \%$.

\section{Referensi}

Adama, Okki, V., Sukartono. (2017). Analisis Densitas Kelurusan untuk Mengetahui Pola Struktur yang Berkembang di Daerah Kebutuhduwur dan Sekitanya Kecamatan Pagedongan, Kabupaten Banjarnegara, Provinsi Jawa Tengah. Yogyakarta, Indonesia. Prosiding Seminar Nasional XII "Rekayasa Teknologi Industri dan Informasi" STTNAS Yogyakarta.

Akuba, A. (4 April 2018). 10 Kelurahan Rawan Longsor, Pemkot Beri Opsi Relokasi Seluruh Warga. Gorontalo: Harian Gorontalo. Sumber URL http://hargo.co.id/berita/10-kelurahan-rawanlongsor-pemkot-beri-opsi-relokasi-seluruh-warga.html

Arifin, S., Carolila, I., Winarso, G. (2006). Implementasi Penginderaan Jauh dan SIG untuk Inventarisasi Daerah Rawan Bencana Longsor (Provinsi Lampung). Penginderaan Jauh dan Pengolahan Citra Digital, 3, 77-86.

Barus, B. (1999). Pemetaan Bahaya Longsoran Berdasarkan Klasifikasi Statistik Peubah Tunggal Menggunakan SIG: Studi Kasus Daerah Ciawi-Puncak-Pacet, Jawa Barat. Jurnal Ilmu Tanah Dan Lingkungan, 2, 7-16.

[BNPB] Badan Nasional Penanggulangan Bencana (5 April 2019). Statistik kejadian tanah longsor. Citing Internet sources URL http://dibi.bnpb.go.id/.

Chemong, C.A., Piyaphong, C. (2013). Fracture Density Analysis in the Sai Yok Fault, Western Thailand and its Implications for Hydrological Exploration. Research Journal of Applied Sciences. 125-130. doi: 10.3923/rjasci.2013.125.130.

Daneshvar, M.R.M., Ali, B. (2011). Landslide Hazard Zonation Assessment using GIS Analysis at Golmakan Watershed, Northeast of Iran. 70-81. doi: 10.1007/s11707-011-0151-8.

Dewi, T.S., Sari, B.K., Heru, S.P. (2017). Zonasi Rawan Bencana Tanah Longsor dengan Metode Analisis GIS: Studi Kasus Daerah Semono dan Sekitarnya, Kecamatan Bagelen, Kabupaten Purworejo, Jawa Tengah. Jurnal Mineral, Energi, dan Lingkungan, 1, 50-59.

Dudal, R., \& Soepraptohardjo, M. 1957. Soil Classification in Indonesia. Cont. Gen. Agr. Res. Sta. No. 148. Bogor.

Hung, L.Q., Batelaan O., De Smedt F. (2005). Lineament Extraction and Analysis, Comparison of Landsat ETM and ASTER Imagery, Case study: Suoimuoi Tropical Karst Catchment, Vietnam. Proceedings of SPIE - The Internasional Society for Optical Engineering, 5983. doi: 10.1117/12.627699.

Pradhan, B., Ahmed, M.Y. 2010. Manifestation of Remote Sensing Data and GIS on Landslide Hazard Analysis using Spatial-Based Statistical Models. 319-326. doi: 10.1007/s12517-009-0089-2. 
Ramani, S.E., Kumarvel, P., Victor, R.G. (2011). GIS Based Landslide Susceptibility Mapping of Tevankarai Ar Sub-Watershed, Kodaikkanal, India using Binary Logistic Regression Analysis. 505517. doi: 10.1007/s11629-011-2157-9.

Rahmat, A.H. (2010). Pemetaan Kawasan Rawan Bencana dan Analisis Resiko Bencana Tanah Longsor dengan Sistem Informasi Geografis (SIG) (Studi Kasus Kawasan Kaki Gunung Ciremai, Kabupaten majalengka). Skripsi. Bogor: Institut Pertanian Bogor.

Sugianti, K., Mulyadi, D., Sarah, D. (2014). Pengklasan Tingkat Kerentanan Gerakan Tanah Daerah Sumedang Selatan Menggunakan Metode Storie. Riset Geologi dan Pertambangan, 24, 93-104.

Sulistiarto, B. (2008). Studi Tentang Identifikasi Longsor dengan Menggunakan Citra Landsat dan Aster. Surabaya: Program Studi Teknik Geomatika FTSP - ITS.

Wahyunto, H., Sastramihardja, H., Supriatna, W., Wahdini W., Sunaryo. (2007). Kerawanan Longsor Lahan Pertanian Di Daerah Aliran Sungai Citarum, Jawa Barat. Prosiding Seminar Nasional Multifungsi dan Konservasi Lahan Pertanian Balai Penelitian Tanah Bogor.

Wang, Z.-Y., Lee, J. H. W. and Melching, C. S. (2015) 'Debris Flows and Landslides', in River Dynamics and Integrated River Management. Berlin, Heidelberg: Springer Berlin Heidelberg, pp. 193264. doi: 10.1007/978-3-642-25652-3_5.

Yunianto, A.C. (2011). Analisis Kerawanan Tanah Longsor dengan Aplikasi Sistem Informasi Geografis (SIG) dan Penginderaan Jauh Di Kabupaten Bogor. Skripsi. Bogor: Institut Pertanian Bogor. 